\title{
Bone marrow and peripheral blood globin chain synthesis in sickle cell $\beta^{\circ}$ thalassaemia
}

\author{
F F COSTA AND M A ZAGO \\ From the Department of Clinical Medicine, School of Medicine, Ribeirão Preto, Brazil.
}

SUMMARY A similar imbalance of globin chain synthesis, with low non- $\alpha / \alpha$ ratios, was shown in peripheral blood and in bone marrow of compound heterozygotes for both the $\mathrm{Hb} S$ and $\beta^{\circ}$ thalassaemia genes $\left(S / \beta^{\circ}\right.$ thalassaemia). Previous purification of whole cell globin obtained from the bone marrow did not change the non- $\alpha / \alpha$ ratio. The mean non- $\alpha / \alpha$ ratios were $0 \cdot 57 \pm 0 \cdot 13$ $(\overline{\mathrm{x}} \pm \mathrm{SD})$ for the peripheral blood of 12 patients, $0 \cdot 52 \pm 0 \cdot 10$ for five patients using bone marrow globin purified on Sephadex G100, and $0.55 \pm 0.16$ for the unfiltered bone marrow globin of five patients. The data show that patients with $S / \beta^{\circ}$ thalassaemia have a similar $\beta$ chain deficiency in reticulocytes and in bone marrow cells, provided whole cell globin is used which avoids the removal of the free $\alpha$ chains. The non- $\alpha / \alpha$ ratios in the peripheral blood of an $S / \beta^{\circ}$ thalassaemia patient and a $\beta$ thalassaemia heterozygote from the same family were compared in seven families and no significant difference was found.

Persons heterozygous for both the haemoglobin $\mathrm{S}$ and the $\beta$ thalassaemia genes ( $S / \beta$ thalassaemia) display a clinical picture that ranges from mild to severe sickle cell syndrome. ${ }^{1-3}$ Globin chain synthesis in the peripheral blood of these patients is unbalanced irrespective of the type of $\beta$ thalassaemia gene inherited, that is, $\beta^{+}$or $\beta^{\circ} .^{24-7}$ In contrast, the results obtained from bone marrow cells are controversial, since both reduced and normal non- $\alpha / \alpha$ ratios have been reported. ${ }^{4} 68-13$ The same discrepancy between peripheral blood and bone marrow globin chain synthesis has been observed in heterozygous $\beta$ thalassaemia. ${ }^{10}$ 13-18

This paper describes the results of bone marrow and peripheral blood globin chain synthesis in a homogeneous group of $S / \beta^{\circ}$ thalassaemia patients and a comparison with simple $\beta$ thalassaemia heterozygotes from the same families.

\section{Patients and methods}

The study included 12 patients with $S / \beta^{\circ}$ thalassaemia, seven relatives with heterozygous $\beta^{\circ}$ thalassaemia, and five $\mathrm{Hb} \mathrm{S}$ homozygotes. Controls consisted of 10 subjects with idiopathic thrombocytopenic purpura, autoimmune haemolytic anaemia, hereditary spherocytic anaemia, or gastrointestinal bleeding. Consent was obtained from all patients (or

Received for publication 24 January 1985.

Revised version accepted for publication 19 March 1985. from one parent) after full explanation of the procedure. Diagnosis was based on clinical and laboratory data, including haematological findings, $\stackrel{\mathbb{Q}}{\varrho}$ electrophoresis on starch gel at $\mathrm{pH} 8.9$ and agar gel $\overrightarrow{\vec{O}}$ at $6 \cdot 1$, quantification of $\mathrm{Hb} \mathrm{A}_{2}$ by elution after $\frac{3}{3}$ electrophoresis on cellulose acetate, measurement of $\mathrm{Hb} \mathrm{F}$ by alkali denaturation, and solubility of the haemolysate in concentrated phosphate buffer. Diagnosis of $S / \beta^{\circ}$ thalassaemia in each case was confirmed by family study, by demonstrating a $\beta \dot{\sigma}$ thalassaemia gene in one parent or in one sib. ${ }^{3}$. Haematological data are shown in table 1 .

Peripheral blood globin chain synthesis was mea-

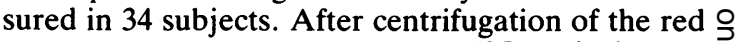
cells at $15000 \mathrm{~g}$ for 60 minutes at $4^{\circ} \mathrm{C}$, reticulocytes $>$ were washed twice in reticulocyte saline (RS) (130을. $\mathrm{mmol} / \mathrm{l} \mathrm{NaCl}, \quad 5 \mathrm{mmol} / \mathrm{l} \mathrm{KCl}, \quad 7.4 \mathrm{mmol} / 1 \mathrm{~N}$ $\mathrm{MgCl}_{2} \cdot 6 \mathrm{H}_{2} \mathrm{O}$ ), and incubated for one hour at $37^{\circ} \mathrm{C}$ 的 in the presence of 50 to $100 \mu \mathrm{Ci} \mathrm{L}-\left[4,5-{ }^{3} \mathrm{H}\right]-\stackrel{N}{O}$ leucine.$^{19}$ For measuring bone marrow globin synth- N esis, about $0.5 \mathrm{ml}$ bone marrow obtained by aspiration was diluted with $5 \mathrm{ml}$ RS containing 1000 units heparin and washed twice in RS. After $\stackrel{\odot}{\mathbb{C}}$ incubation, the cells were washed and lysed by freezing and thawing and the addition of distilled 0 water. Whole cell globin was prepared by acetone- $\bar{O}$ $\mathrm{HCl}$ precipitation immediately after the completion $\stackrel{8}{\circ}$ of the labelling experiment. Whole cell globin (30 to $\underset{\mathbb{\triangle}}{\mathbb{Q}}$ $60 \mathrm{mg}$ ) from bone marrow of five patients was fractionated on a $2.5 \mathrm{~cm}^{2} \times 50 \mathrm{~cm}$ column of 
TABLE 1 Haematological data and globin synthesis ratios in whole cell globin samples from $S / \beta^{\circ}$ thalassaemia, sickle cell anaemia, and controls.

\begin{tabular}{|c|c|c|c|c|c|c|c|}
\hline \multirow[t]{3}{*}{ Case } & \multirow{3}{*}{$\begin{array}{l}H b \\
(g / d l)\end{array}$} & \multirow{3}{*}{$\begin{array}{l}M C H \\
(p g)\end{array}$} & \multirow{3}{*}{$\begin{array}{l}H b F \\
(\%)\end{array}$} & \multirow{3}{*}{$\begin{array}{l}\mathrm{Hb} A_{2} \\
(\%)\end{array}$} & \multicolumn{3}{|c|}{ Non- $\alpha / \alpha$ ratio (total counts) } \\
\hline & & & & & \multirow{2}{*}{$\begin{array}{l}\text { Peripheral } \\
\text { blood }\end{array}$} & \multicolumn{2}{|c|}{ Bone marrow } \\
\hline & & & & & & Original & After Sephadex \\
\hline \multicolumn{8}{|c|}{$S / \beta^{\circ}$ thalassaemia } \\
\hline 1 & $9 \cdot 0$ & $23 \cdot 7$ & $13 \cdot 5$ & 3.9 & 0.41 & (0.45 & 0.39 \\
\hline 2 & $7 \cdot 2$ & $24 \cdot()$ & $6 \cdot 3$ & $4 \cdot 1$ & 0.64 & $0 \cdot 43$ & 0.55 \\
\hline 3 & $8 \cdot 6$ & $21 \cdot 0$ & $7 \cdot 8$ & $6 \cdot 0$ & 0.76 & 0.53 & 0.50 \\
\hline 4 & $8 \cdot 8$ & $25 \cdot 1$ & $6 \cdot 2$ & $4 \cdot 8$ & 0.52 & $0 \cdot 82$ & \\
\hline 5 & $8 \cdot 5$ & $21 \cdot 8$ & $9 \cdot 9$ & $6 \cdot 4$ & $0 \cdot 61$ & 0.51 & \\
\hline 6 & $8 \cdot 4$ & $22 \cdot 7$ & $2 \cdot 9$ & $5 \cdot 4$ & 0.41 & & 0.68 \\
\hline 7 & $8 \cdot 6$ & $20 \cdot 1$ & $7 \cdot 9$ & 5.6 & 0.42 & & $0 \cdot 50$ \\
\hline 8 & $4 \cdot 6$ & $24 \cdot 2$ & $6 \cdot 9$ & $4 \cdot 2$ & $0 \cdot 67$ & & \\
\hline 9 & $8 \cdot 5$ & $26 \cdot 6$ & $21 \cdot 4$ & 3.9 & 0.52 & & \\
\hline 10 & $9 \cdot 5$ & $22 \cdot 6$ & $1 \cdot 0$ & $5 \cdot 8$ & 0.77 & & \\
\hline 11 & $5 \cdot 5$ & $22 \cdot 5$ & $9 \cdot 5$ & $3 \cdot 5$ & 0.65 & & \\
\hline 12 & $8 \cdot 7$ & $20 \cdot 2$ & 5.7 & $5 \cdot 6$ & 0.52 & & \\
\hline Mean \pm SD & $8 \cdot 0 \pm 1 \cdot 5$ & $22 \cdot 9 \pm 1 \cdot 9$ & $8 \cdot 2 \pm 5 \cdot 2$ & $4 \cdot 9 \pm 1 \cdot()$ & $0.57 \pm 0 \cdot 13$ & $0 \cdot 55 \pm 0 \cdot 16$ & $(0.52 \pm 0 \cdot 10$ \\
\hline \multicolumn{8}{|c|}{ SS homozygotes $(n=5)$} \\
\hline Mean \pm SD & $8 \cdot 5 \pm 0 \cdot 9$ & $33 \cdot 4 \pm 3 \cdot 1$ & $4 \cdot 7 \pm 3 \cdot 4$ & $2 \cdot 8 \pm(0 \cdot 3$ & $1 \cdot(0) \pm(0 \cdot() 8$ & $0.98 \pm\left(0 \cdot 12^{*}\right.$ & \\
\hline \multicolumn{8}{|c|}{ Controls $(n=10)$} \\
\hline Mean \pm SD & $10 \cdot 0 \pm 2 \cdot 8$ & $30 \cdot 4 \pm 3 \cdot 4$ & $0 \cdot 7 \pm 0 \cdot 3$ & $2 \cdot 7 \pm 0 \cdot 4$ & $1 \cdot(02 \pm 0 \cdot 08$ & $1 \cdot 10 \pm(0 \cdot 12 \dagger$ & \\
\hline
\end{tabular}

$* n=4 . \quad+n=8$

TABLE 2 Comparison of peripheral blood non- $\alpha / \alpha$ ratios for an $S / \beta^{\circ}$ thalassaemia patient and a $\beta$ thalassaemia heterozygote from the same family.

\begin{tabular}{lll}
\hline Family & Non-wa ratio (total counts) & \\
\cline { 2 - 3 } & Patient & Relative \\
\hline 01 & 0.41 & 0.45 \\
02 & 0.64 & 0.47 \\
05 & 0.61 & 0.51 \\
06 & 0.41 & 0.38 \\
08 & 0.67 & 0.80 \\
10 & 0.77 & 0.51 \\
11 & 0.65 & 0.43 \\
Mean \pm SD & $0.59 \pm 0.13$ & $0.51 \pm 0.14$ \\
\hline
\end{tabular}

Sephadex $\mathrm{G} 100^{20}$ in $1 \% \mathrm{v} / \mathrm{v}$ formic acid at a flow rate of $0.15 \mathrm{ml} / \mathrm{minute}$ at room temperature. Blue Dextran was added as a marker and a considerable proportion of the radioactivity eluted with the unretarded blue Dextran peak. All material that eluted after this initial fraction was freeze dried and subsequently analysed on CM-cellulose. Globin separation was carried out by $\mathrm{CM}$-cellulose chromatography. ${ }^{19}$ The non- $\alpha / \alpha$ ratios were calculated on the basis of the total count in each entire chromatographic peak corresponding to the $\gamma, \beta, \beta^{\mathrm{S}}$, and $\alpha$ chains.

\section{Results}

The results of the globin synthesis ratios are summarised in table 1 . The non- $\alpha / \alpha$ ratios in peripheral blood were $0 \cdot 57 \pm 0 \cdot 13$ (mean $\pm S D)$ for 12 patients with $S / \beta^{\circ}$ thalassaemia, $1.00 \pm 0.08$ for five $\mathrm{Hb} S$ homozygotes, and $1.02 \pm 0.08$ for 10 controls.

The morphological observation of bone marrow smears from $S / \beta^{\circ}$ thalassaemia patients showed a significant erythroid hyperplasia and the specific activity of the globin obtained from bone marrow was five to 100 times higher than that of peripheral blood of the same patient. Bone marrow globin synthesis ratios were measured in whole cell globin from seven patients with $S / \beta^{\circ}$ thalassaemia, and there was no significant difference between the mean non- $\alpha / \alpha$ ratios in globin after purification on Sephadex G100 and those in unfiltered globin $(0 \cdot 52 \pm 0 \cdot 10$ and $0.55 \pm 0 \cdot 16$ respectively). These values are similar to those observed in peripheral blood of the same patients $(p>0 \cdot 05$, rank sum test on paired data).

\section{Discussion}

Although the $\beta$ thalassaemias are highly heterogeneous at the molecular level, these Brazilian patients with $S / \beta^{\circ}$ thalassaemia represent a 
homogeneous group, at least from the ethnic standpoint, since in all cases the $\beta^{\circ}$ thalassaemia gene was of Italian origin. Furthermore, the globin synthesis ratios analysed in the present study were not strictly dependent on the molecular defect of the $\beta^{\circ}$ thalassaemia gene since no synthesis of $\beta^{\mathrm{A}}$ chains was observed. The occurrence of $\alpha$ thalassaemia has not been excluded, but this does not invalidate our results because $\alpha$ thalassaemia would be expected to increase the non- $\alpha / \alpha$ ratios.

Our results for seven patients with $S / \beta^{\circ}$ thalassaemia show that the imbalance of globin synthesis in bone marrow is equivalent to that found in peripheral blood reticulocytes, provided whole cell globin is used, which avoids the removal of free $\alpha$ chains. Balanced globin synthesis in bone marrow has been reported for most of the cases of $S / \beta$ thalassaemia studied so far; the majority of the patients had $S / \beta^{+}$thalassaemia. ${ }^{4}{ }^{8-12}$ The question of globin synthesis in bone marrow of carriers of a single $\beta$ thalassaemia gene (simple heterozygotes and $S / \beta$ thalassaemia compound heterozygotes) has been complicated by conflicting results since the report of balanced synthesis by Schwartz. ${ }^{16}$ The majority of subsequent studies confirmed the finding of balanced synthesis ${ }^{17}$ and several hypotheses have been presented to explain the discrepancy between the results obtained in peripheral blood and in bone marrow. The apparently balanced synthesis in bone marrow could be the consequence of unstable $\beta$ thalassaemic mRNA, ${ }^{10}$ a compensatory increase of $\beta$ chain synthesis by the normal $\beta$ gene in the erythroid precursors, ${ }^{10}$ or increased proteolytic activity removing the excess of $\alpha$ chains from these cells. ${ }^{13} 18$ It could also be artefactual or the result of methodological problems such as the presence of non-globin proteins which cochromatograph with the $\beta$ chains ${ }^{11}{ }^{19-21}$ or the preferential loss of $\alpha$ chains during storage, precipitation of globin, or handling of the material. The contamination of the $\beta$ peak by non-globin proteins, probably of non-erythroid origin, has been fully documented. ${ }^{20}$ However, this should not greatly affect the non- $\alpha / \alpha$ ratios of patients with $S / \beta^{\circ}$ thalassaemia, since they have a significant erythroid hyperplasia of bone marrow. Moreover, $\beta^{S}$ chains elute later than $\beta^{A}$ chains during chain separation and Chalevelakis $e t a l^{20}$ have shown that the bulk of non-globin contaminating proteins run in the early part of the chromatogram. In agreement with this, the filtration of whole cell globin on Sephadex G100 did not significantly change the mean non- $\alpha / \alpha$ ratios of our patients. However, a higher ratio was obtained for one patient in bone marrow $(0.82)$ than in peripheral blood $(0.52)$ with unfiltered globin (case 4, table 1), and Ladas et al ${ }^{11}$ observed that filtration of globin reduced the bone marrow non$\alpha / \alpha$ ratio in one of two cases.

The majority of previous studies of globin synthesis in bone marrow of patients with $S / \beta$ thalassaemia and of $\beta$ thalassaemia heterozygotes have been carried out with stroma free globin. ${ }^{46} 81216$ So far, unbalanced globin synthesis in bone marrow of patients with $\beta$ thalassaemia in association with $\beta$ globin structural variants has been reported for five $\mathrm{S} / \beta^{+}$thalassaemia patients out of eight investigated by Bank et $a l^{4}$ and Ladas et al,,$^{11}$ as well as for one case each of $\mathrm{Hb} \mathrm{S} / \beta^{\circ}$ thalassaemia, ${ }^{22} \mathrm{Hb} \mathrm{D} / \beta^{\circ}$ thalassaemia ${ }^{23}$ and $\mathrm{Hb} \mathrm{E} / \beta^{\circ}$ thalassaemia. ${ }^{24}$ In six of these cases the studies were carried out with whole cell globin. Thus, contamination of the $\beta$ chain peak and proteolysis of the $\alpha$ chains may contribute in part to changing the ratio towards balance, but it seems that the main reason for obtaining a balanced non- $\alpha / \alpha$ ratio in bone marrow from $S / \beta$ thalassaemia patients is the use of stroma free globin with removal of the free $\alpha$ chains with the stroma.

Our results, showing an unbalanced globin synthesis in the bone marrow of $S / \beta^{\circ}$ thalassaemia patients, are in agreement with those reported by Chalevelakis et $a l^{21}$ for simple $\beta$ thalassaemia heterozygotes. This finding is not unexpected since peripheral blood $\beta^{\mathrm{S}} / \alpha$ and $\beta^{\mathrm{A}} / \alpha$ ratios, respectively, are similar for the two diseases.

Finally, the comparison of globin chain synthesis in peripheral blood of patients with $S / \beta^{\circ}$ thalassaemia and that of their relatives with heterozygous $\beta^{\circ}$ thalassaemia has shown that the imbalance of chain synthesis was similar for the two groups (table 2). This finding represents indirect evidence that the genes in trans position with the thalassaemia gene $\left(\beta^{\mathcal{S}}\right.$ or $\beta^{\mathrm{A}}$, respectively) have similar synthetic activities.

This work was partly supported by Fundação de Amparo à Pesquisa do Estado de S Paulo and $\mathrm{CNPq}$. The authors are indebted to Dr R Lewinsohn for her help in preparing the manuscript and to $\mathrm{M} \mathrm{H}$ Tavella, M H Silva, and A G Araújo for their expert technical help.

\footnotetext{
References

1 Serjeant GR, Ashcroft MT. Serjeant B, Milner PF. The clinical features of sickle cell/ $\beta$-thalassemia in Jamaica. $\mathrm{Br} J$ Haematol 1973;24:19-30.

2 Weatherall DJ, Clegg JB. The thalassaemia syndromes. 3rd ed. Oxford: Blackwell Scientific Publications, 1981.

${ }^{3}$ Zago MA, Costa FF, Freitas TC, Bottura C. Clinical, hematological and genetic features of sickle cell- $\beta$ thalassemia in a Brazilian population. Clin Genet 1980;18:58-64.

${ }^{4}$ Bank A, Dow LW, Farace MG, O’Donnell JV, Ford S, Natta C. Changes in globin synthesis with erythroid cell maturation in sickle thalassemia. Blood 1973:41:353-7.

5 Kim HC. Variants of sickle cell disease. In: Schwartz E, ed.
} क 
Hemoglobinopathies in children. Littleton, Ma: PSG Publishing Company, 1980:215.

- Kim HC, Weierbach RG, Friedman S, Schwartz E. Detection of sickle $\alpha$ or $\beta^{\circ}$-thalassemia by studies of globin biosynthesis. Blood 1977;49:785-92.

7 Weatherall DJ, Clegg JB, Na-Nakorn S, Wasi P. The pattern of disordered haemoglobin synthesis in homozygous and heterozygous $\beta$-thalassaemia. Br J Haematol 1969;16:257-67.

${ }^{8}$ Gill FM, Schwartz E. Synthesis of globin chains in sickle $\beta$ thalassemia. J Clin Invest 1973;52:709-14.

${ }^{9}$ Gill FM, Schwartz E. Free $\alpha$-globin pool in human bone marrow. J Clin Invest 1973;52:3057-63.

${ }^{10} \mathrm{Kan}$ YW, Nathan DG, Lodish HF. Equal synthesis of $\alpha$ and $\beta$ globin chains in erythroid precursors in the heterozygous $\beta$ thalassemia. J Clin Invest 1972;51:1906-9.

" Ladas S, Chalevelakis G, Lyberatos C, Vaidakis E, Arapakis G. Globin chain synthesis in sickle $\beta$-thalassaemic bone marrow and reticulocytes. J Med Genet 1979;16:296-301.

${ }_{12}$ Neinhuis AW, Canfield PH, Anderson WF. Hemoglobin messenger RNA from human bone marrow: isolation and translation in homozygous and heterozygous $\beta$-thalassemia. $J$ Clin lnvest 1973;52:1735-45.

13 Wood WG, Stamatoyannopoulos G. Globin synthesis in fractionated normoblasts of $\beta$-thalassemia heterozygotes. $J$ Clin Invest 1975;55:567-78.

${ }^{14}$ Clegg JB, Weatherall DJ. Haemoglobin synthesis during erythroid maturation in $\beta$-thalassaemia. Nature 1972;240:190-2.

15 Gallo E, Pich PG, Ricco G, Saglio G, Camaschella C, Mazza U. The relationship between anemia, fecal stercobilinogen, erythrocyte survival and globin synthesis in heterozygotes for $\beta$ thalassemia. Blood 1975;46:693-8.
${ }^{16}$ Schwartz E. Heterozygous beta thalassemia: balanced globin synthesis in bone marrow cells. Science 1970;167:1513-4.

17 Schwartz E. Abnormal globin synthesis in thalassemic red cells. Semin Hematol 1974;11:549-67.

${ }^{18}$ Benz EJ Jr, Pritchard J, Hillman D, Glass J, Forget BG. $\beta$ globin messenger RNA content of bone marrow erythroblasts in heterozygous $\beta$-thalassemia. Am J Hematol 1984;16:33-45.

${ }^{19}$ Clegg JB. Haemoglobin synthesis. In: Weatherall DJ, ed. The thalassaemias. Edinburgh: Churchill Livingstone, 1983:54.

${ }^{20}$ Chalevelakis G, Clegg JB, Weatherall DJ. Globin synthesis in normal human bone marrow. Br J Haematol 1976;34:535-57.

${ }^{21}$ Chalevelakis G, Clegg JB. Weatherall DJ. Imbalanced globin chain synthesis in heterozygous $\beta$-thalassemic bone marrow. Proc Natl Acad Sci USA 1975;72:3853-7.

22 Rieder RF. Variation in $\beta / \alpha$ synthesis ratios in thalassemia and hemoglobinopathies. Ann NY Acad Sci 1974;232:44-53.

${ }^{23}$ Rieder RF. Globin chain synthesis in HbD (Punjab)- $\beta^{\circ}$ thalassemia. Blood 1976;47:113-20.

24 Testa U. Dubart A. Hinard $\mathrm{N}$, et al. $\beta^{\circ}$-thalassaemia/HbE association. Haemoglobin synthesis in blood reticulocytes and bone marrow cells fractionated by density gradient and in blood erythroid colonies in culture. Acta Haematol (Basel) 1980;64:42-52.

Correspondence and requests for reprints to $\mathrm{Dr}$ Marco A Zago, Department of Clinical Medicine, School of Medicine, 14100 Ribeirão Preto, São Paulo, Brazil. 